\title{
Development of Coastal Flow and Transport Models in Support of Everglades Restoration
}

\author{
By 'Christian D. Langevin, 'Eric D. Swain, '3ohn D. Wang, 'Melinda A. Wolfert, \\ ${ }^{2}$ Raymond W. Schaffranek, and ${ }^{2}$ Ami L. Riscassi \\ U.S. Geological Survey, ${ }^{1}$ Miami, FL, ${ }^{2}$ Reston, VA; ${ }^{3}$ Rosenstiel School of Marine and Atmospheric Science, Univ. of Miami, FL
}

The U.S. Geological Survey is actively involved in science support for Everglades restoration. This paper summarizes the development and application of two integrated surfacewater/ground-water flow and transport models for the southern Everglades of Florida. Key points of this modeling effort include the following:

- The Southern Inland and Coastal Systems (SICS) model represents hydrologic conditions for the Taylor Slough area with 305-meter grid resolution.

- The Tides and Inflows in the Mangroves of the Everglades (TIME) model encompasses a larger area than SICS, including both Taylor and Shark River Sloughs, and uses 500-meter grid resolution.

- The SICS model is fully operational and is being used as part of the Florida Bay/Florida Keys Feasibility
Study (FBFKFS) to assess freshwater flows to northeastern Florida Bay.

- The TIME model is under calibration and is also being used as part of FBFKFS to assess freshwater flows to the Gulf of Mexico.

- A procedure has been developed for running the coastal flow and transport models with output from the South Florida Water Management Model (SFWMM). This procedure allows for the prediction of detailed coastal wetland flows and salinities under various restoration scenarios tested with the SFWMM.

- Results from SICS and TIME are being used as input to ecological models to predict the effects of Everglades restoration on species populations.

\section{Introduction}

Coastal wetlands are unique hydrologic environments between inland freshwater systems and marine estuaries. The development of methods and tools to understand and predict hydrologic conditions within coastal wetlands has been limited due to a lack of field data, and the complexity and number of relevant hydrologic processes, such as tidal and wind forcing, evapotranspiration, overland flow through emergent vegetation, salinity-induced density-dependent flow, and surface-water/ ground-water interactions. In southern Florida, the need for robust numerical methods to simulate coastal wetland hydrologic processes, including the mixing of saltwater and freshwater within a coastal mangrove fringe, was motivated by the ongoing effort to restore the Everglades and Florida Bay. In response to the Comprehensive Everglades Restoration Plan (CERP) to substantially increase flows through the Everglades, the U.S. Geological Survey (USGS) and other agencies initiated large research and data-collection programs to better understand coastal hydrologic processes and characterize baseline pre-restoration conditions. One area that received considerable attention was Taylor Slough-the main contributor of freshwater to northeastern Florida Bay. The large hydrologic database for the Taylor Slough area provided a unique opportunity to characterize hydrologic processes through the development of a numerical model.

In 1996, the USGS initiated development of the Southern Inland and Coastal Systems (SICS) model (fig. 1). SICS was originally developed to synthesize the large volume of field data collected in the Taylor Slough area by improving upon an existing hydrodynamic surface-water flow and transport code; namely SWIFT2D (Leendertse, 1987), and using the enhanced code (Schaffranek, 2004; Swain and others, 2004) to characterize flow and salinity patterns in the coastal wetland and adjacent Florida Bay estuary. As part of SICS development, new algorithms were formulated for incorporating effects of rainfall, evapotranspiration, wind sheltering, and the effect of vegetation and microtopography on overland flow (Swain and others, 2004). When applied to the Taylor Slough area, these new methods substantially improved the ability of the model to represent coastal hydrologic processes, particularly freshwater discharges to northeastern Florida Bay and coastal wetland salinities.

The USGS has continued to expand upon the initial SICS modeling approach through: (1) scientific research to improve the representation of hydrologic processes (for example, surface- and ground-water interactions), (2) development of the Tides and Inflows in the Mangroves of the Everglades (TIME) model for Taylor and Shark River Sloughs (fig. 1), and (3) application of SICS and TIME for Everglades restoration. The SICS and TIME models are continuously evolving as new data are collected and the ability to represent hydrologic processes improves. As the only hydrodynamic models capable of simulating and predicting detailed flow and salinity patterns in the southern Everglades, SICS and TIME show great promise for the continued support of Everglades restoration. 


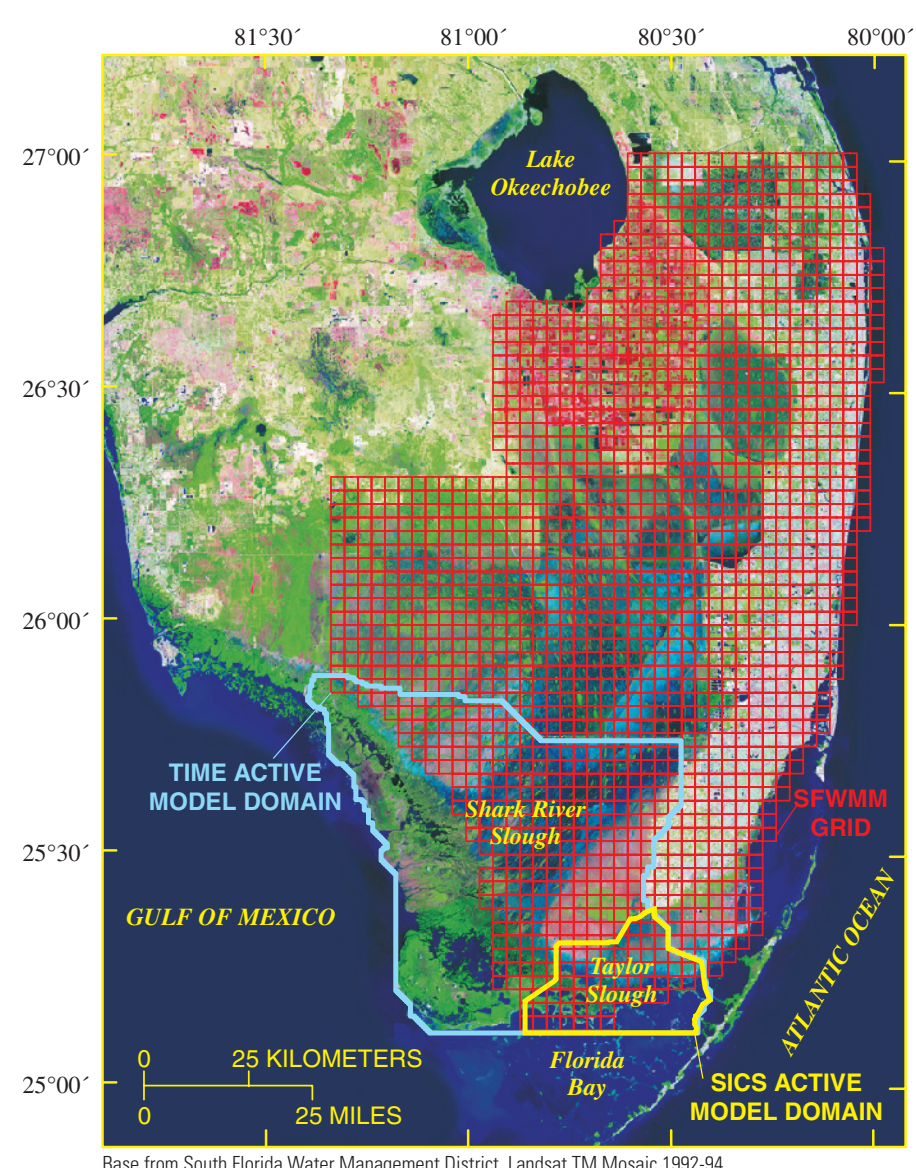

Base from South Florida Water Management District, Landsat TM Mosaic 1992-94 Universal Transverse Mercator projection, Zone 17, Datum NAD 27

Figure 1. Map of southern Florida showing the active model domains of SICS and TIME and the SFWMM grid.

\section{Surface-Water/Ground-Water Interactions}

In the southern Everglades of Florida, where the shallow surficial aquifer system consists of highly permeable limestone, interactions between surface water and ground water comprise a large part of the water budget (Harvey and others, 2000a; 2000b). As part of the SICS and TIME modeling effort, a method was developed for simulating the exchange of fluid and salt between the wetland and underlying aquifer system (fig. 2). The method was implemented by combining SWIFT2D with the SEAWAT variable-density ground-water flow and transport code (Guo and Langevin, 2002). The integrated code simulates surface-water and ground-water interactions between a wetland and aquifer, and is called Flow and Transport in a Linked Overland/Aquifer Density Dependent System (FTLOADDS). The mass-conserving approach for the explicit coupling between SWIFT2D and SEAWAT, which is based on a variable-density form of Darcy's Law, is given in Langevin and others (2004).

FTLOADDS was applied to the SICS area to quantify the importance of surface-water and ground-water exchanges and to improve the original SICS model as a management tool (Langevin and others, 2004). Results from the integrated model demonstrate the importance of surface-water and ground-water exchanges within the Taylor Slough area. Average annual leakage rates between the wetland and aquifer for a 7-year simulation period (1996-2002) indicate an alternating pattern of upward and downward flow (fig. 3). This pattern is primarily related to topographic variations within the SICS

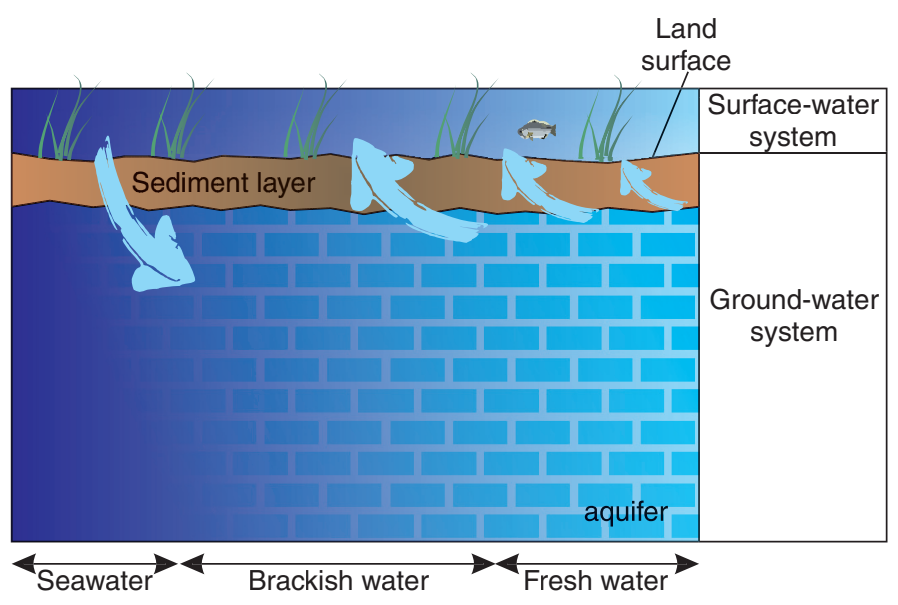

Figure 2. Conceptual model for surface- and ground-water interactions as implemented in the Flow and Transport in a Linked Overland/ Aquifer Density Dependent System (FTLOADDS) computer code, which is a coupled version of SWIFT1D and SEAWAT.

area, but is also dependent on subsurface variations in fluid density. Figure 3 indicates that leakage rates in some areas can be similar in magnitude to rainfall, the primary source of water within the SICS area. Daily average rainfall rate is about 0.4 centimeter per day. The magnitude of these exchanges supports the general belief that surface-water and ground-water interactions in southern Florida must be accounted for in quantitative hydrologic studies.

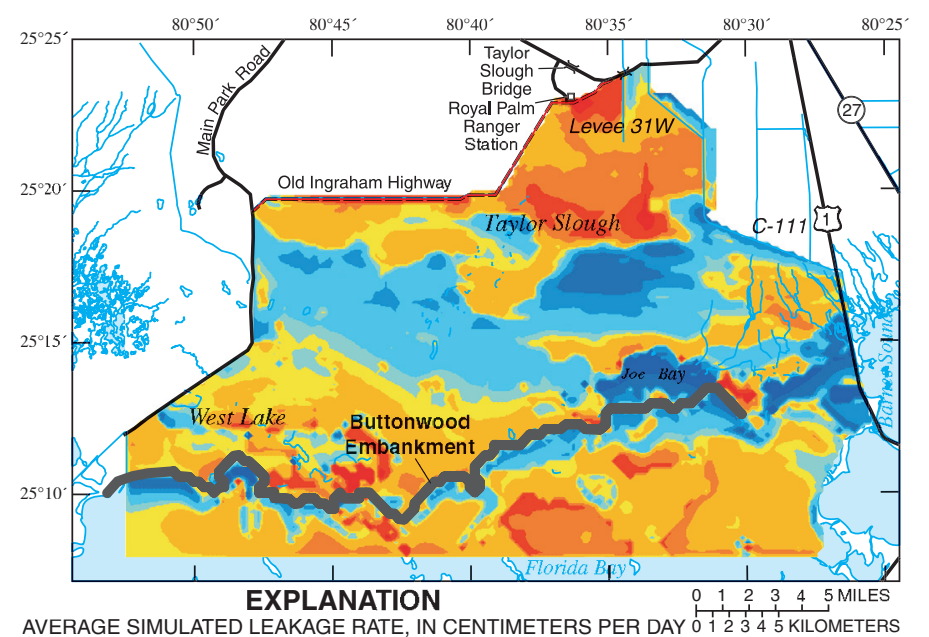

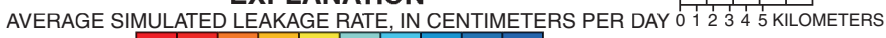

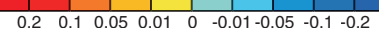

Figure 3. Average annual surface-water budget for the coastal wetland for the 7-year simulation period (1996-2002). Positive values indicate downward flow into the aquifer (from Langevin and others, 2004).

\section{The TIME Model}

The methodology used for the SICS model is being expanded and improved for the development of the TIME model. TIME is coarser in resolution (500 meters) than SICS (305 meters), but covers a much larger area of the Everglades, including Shark River and Taylor Sloughs to the Gulf of Mexico and northern Florida Bay (fig. 1). Although TIME encompasses the SICS model domain, the SICS model could be used in the future to provide detailed simulations for the Taylor Slough area. The TIME model also is being developed using the FTLOADDS 
computer program, and thus, the type of output from both models is similar and consists of flows, stages, and salinities in the wetlands and underlying aquifer system.

An application of the TIME model as a tool to evaluate the effects of CERP scenarios on freshwater flows to Florida Bay and the Gulf of Mexico began in late 2003. Presently, the model is being calibrated and verified with data collected from 1996 to 2002 in preparation for simulation of different scenarios. This effort entails comparing computed and observed stages and flows to elucidate model behavior and to develop measures of model accuracy. An example of computed surface-water depth during the wet season is shown in figure 4.

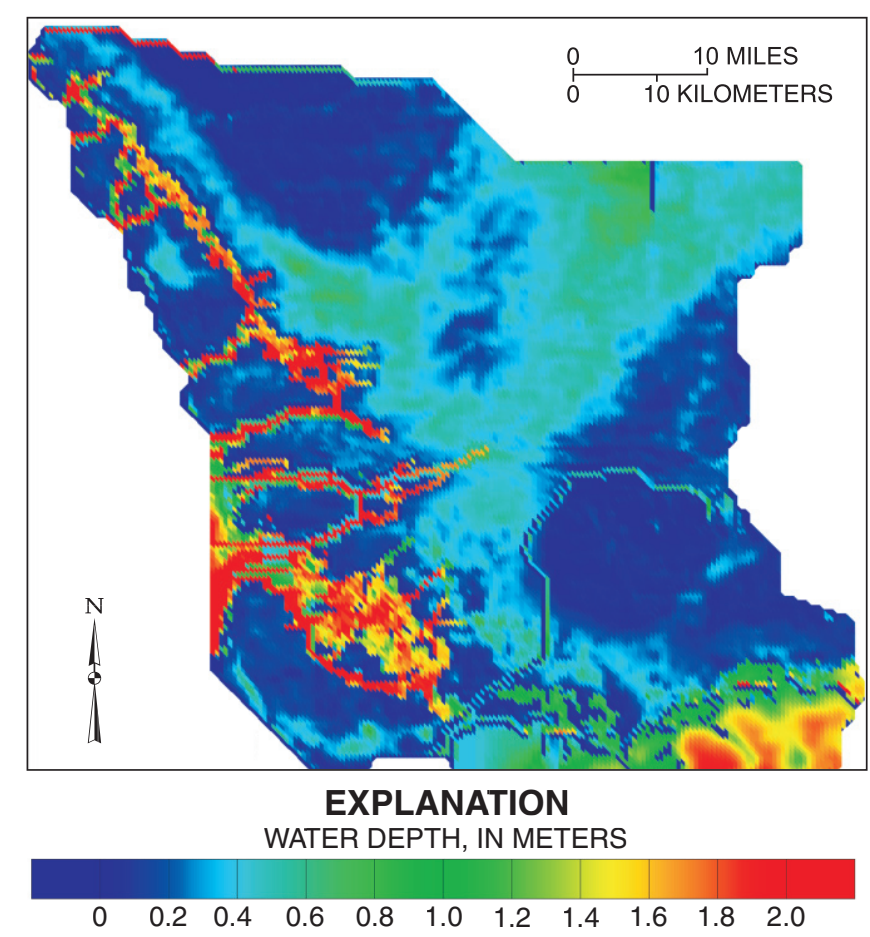

Figure 4. Example of simulated water depths from the TIME model.

\section{Application of SICS and TIME for Everglades Restoration}

Numerical models of surface- and ground-water flow are essential analysis tools in the Everglades restoration process. Restoration alternatives are tested and evaluated prior to implementation by simulating hydrologic conditions that would result from proposed modifications to the existing system. The South Florida Water Management Model (SFWMM), or " 2 by 2," which refers to the 2- by 2-mile finite-difference grid, was developed by the South Florida Water Management District (SFWMD) to simulate the complex hydrologic conditions in southern Florida and to evaluate restoration alternatives (MacVicar and others, 1984; South Florida Water Management District, 1997). The SFWMM is an advanced and comprehensive management tool that covers most of southern Florida (fig. 1) and represents canal, overland, and ground-water flows and the interactions between them. As with any model, the SFWMM has limitations. For example, the SFWMM is best at simulating surface-water stage and ground-water head, but is less reliable when it comes to simulating flow rates. Additionally, the SFWMM does not contain solute-transport capabilities, and thus, there is no direct way to predict the effects of restoration scenarios on coastal wetland and aquifer salinities. These limitations affect studies of Florida Bay, which require accurate predictions of freshwater flows into the estuary. The 2-mile-square cell size of the SFWMM also yields inadequate spatial resolution of hydrologic variability in the wetlands for the development of accurate and representative ecological species models. These species models are being used to guide and evaluate restoration efforts by predicting future populations of fish, alligators, and other organisms.

The SICS and TIME models are being applied to support Everglades restoration by bridging the gap between the SFWMM, the Florida Bay hydrodynamic model, and the ATLSS (Across Trophic Level System Simulation) ecological models (fig. 5). A key component in this application is the method developed by Wolfert and others (2004), which allows SICS model boundaries to be assigned based on stages from a SFWMM baseline or restoration simulation. This link to the SFWMM extends the capability of SICS to predict coastal flows to Florida Bay and coastal wetland salinities under future restoration conditions. A similar link is planned for the TIME model.

There are two ongoing efforts related to simulating restoration conditions with SICS and TIME. The first effort is funded under CERP as part of the Florida Bay/Florida Keys Feasibility Study (FBFKFS). A hydrodynamic model of Florida Bay is currently being developed as part of the FBFKFS with a primary objective of quantifying the effects of Everglades restoration on the Florida Bay estuary (Hamrick and Moustafa, 2003). The USGS is playing an integral role in that study by estimating past freshwater flows and predicting future flows to northeastern Florida Bay (SICS model) and to the Gulf of Mexico (TIME model). Future plans include the development of a water-quality module for SICS and TIME that can be used to predict nutrient loads to Florida Bay. The water-quality modeling will build on the work of Levesque (2004), which describes water and nutrient fluxes along the southwestern Florida coast.

The second effort involves the use of SICS and TIME to provide landscape hydrology input for the ATLSS ecological models (fig. 6). A specific example of this application is the use of SICS model output to drive the ATLSS ALFISHES model.

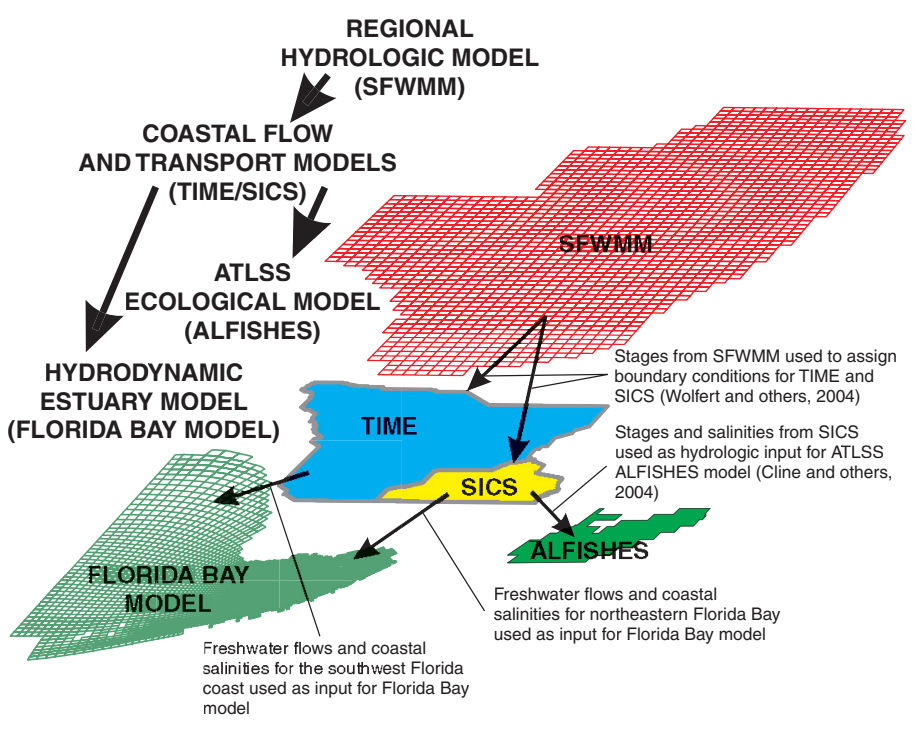

Figure 5. Schematic showing the relation between the SICS and TIME models and the SFWMM, ALFISHES, and Florida Bay models. 
ALFISHES is an extension of a preexisting ATLSS model (ALFISH) for functional fish groups in freshwater marshes in the Greater Everglades area of southern Florida. ALFISHES was designed to evaluate the spatial and temporal patterns of fish density in the Everglades mangrove zone of Florida Bay. Each of the ALFISHES model cells is divided into two habitat types: flats that are flooded only during the wet season, and creeks that are always wet and serve as refugia during the dry season. Fish movement, production, and die-out are a function of flooding and drying and salinity. Water-level and salinity data generated by the SICS model are used as input to the ALFISHES model to define these interactions (Cline and others, 2004). With the development of restoration scenario capabilities in the SICS model, the SICS/ALFISHES coupling is an effective tool for evaluating the potential effect of hydrologic changes on fish populations in the Everglades mangrove zone. Future applications will be expanded to include crocodiles and alligators.

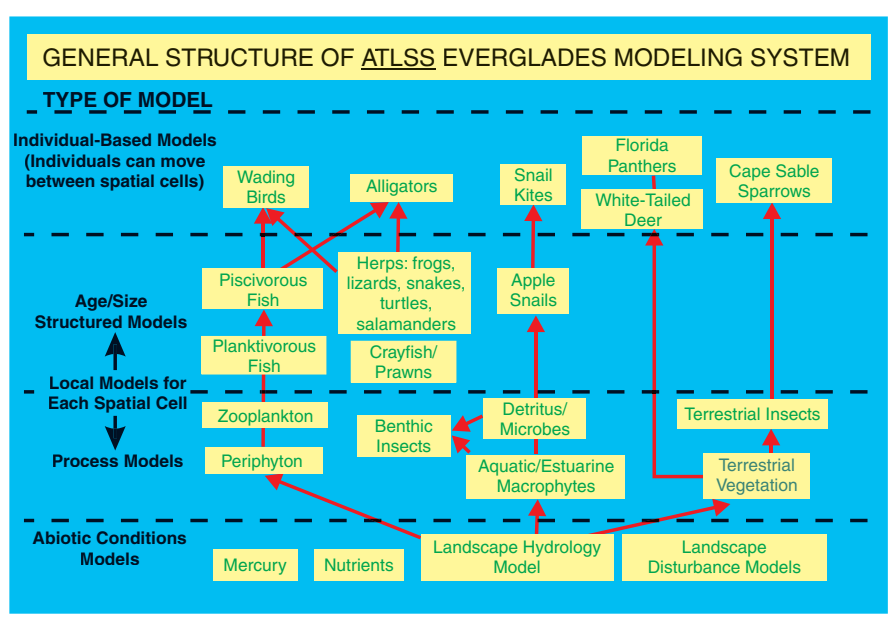

Figure 6. General structure of the Across Trophic Level Systems Simulation (ATLSS) modeling system showing the importance of landscape hydrology to ecological models.

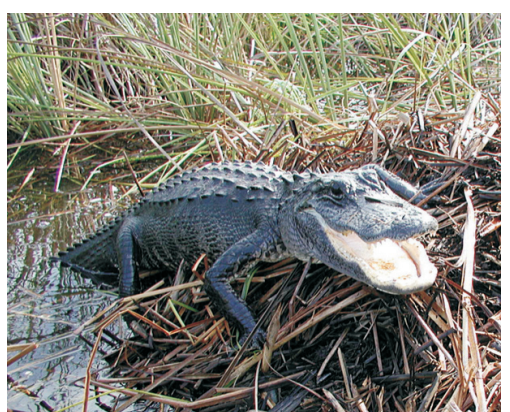

(Photograph by Lori Oberhofer, courtesy National Park Service

\section{References}

Cline, J.C., Lorenz, Jerome, and Swain, E.D., 2004, Linking hydrologic modeling and ecologic modeling: An application of adaptive ecosystem management in the Everglades mangrove zone of Florida Bay: International Environmental Modelling and Software Society iEMSs 2004 International Conference, 14-17 June 2004, University of Osnabrïck, Germany.

Guo, Weixing, and Langevin, C.D., 2002, User's guide to SEAWAT: A computer program for simulation of three-dimensional variable-density ground-water flow: U.S. Geological Survey Techniques of Water-Resources Investigations, book 6, chap. A7, $77 \mathrm{p}$.

Hamrick, J.M., and Moustafa, M.Z., 2003, Florida Bay hydrodynamic and salinity model analysis: 2003 Proceedings of the Greater Everglades and Florida Bay Ecosystem Conference, Palm Harbor, Florida, April 13-18, 2003.

Harvey, J.W., Choi, J., and Mooney, R.H., 2000a, Hydrologic interactions between surface water and ground water in Taylor Slough, Everglades National Park, in U.S. Geological Survey Program on the South Florida Ecosystem: 2000 Proceedings of the Greater Everglades Ecosystem Restoration (GEER) Conference, December 11-15, 2000, edited by Eggleston and others: U.S. Geological Survey Open-File Report 00-449, p. 24-26.

Harvey, J.W., Jackson, J.M., Mooney, R.H., and Choi, J., 2000b, Interactions between ground water and surface water in Taylor Slough and vicinity, Everglades National Park, south Florida: Study methods and appendixes: U.S. Geological Survey Open-File Report 00-483, 67 p.

Langevin, C.D., Swain, E.D., and Wolfert, M.A., 2004, Simulation of integrated surface-water/ground-water flow and salinity for a coastal wetland and adjacent estuary: U.S. Geological Survey Open-File Report 2004-1097, 30 p.

Leendertse, J.J., 1987, Aspects of SIMSYS2D, a system for two-dimensional flow computation: Santa Monica, Calif., Rand Corporation Report R-3572USGS, $80 \mathrm{p}$.
Levesque, V.A., 2004, Water flow and nutrient flux from five estuarine rivers along the southwest coast of Everglades National Park, Florida: U.S. Geological Survey Scientific Investigations Report 2004-5142.

MacVicar, T., Van Lent, T., and Castro, A., 1984, South Florida Water Management Model documentation report: West Palm Beach, South Florida Water Management District Technical Publication 84-3.

Schaffranek, R.W., 2004, Simulation of surface-water integrated flow and transport in two dimensions: SWIFT2D user's manual: U.S. Geological Survey Techniques and Methods, book 6, chap.1, section B, 115 p.

South Florida Water Management District, 1997, DRAFT Documentation for the South Florida Water Management Model: West Palm Beach, Florida, South Florida Water Management District Report.

Swain, E.D., Wolfert, M.A., Bales, J.D., and Goodwin, C.R., 2004, Twodimensional hydrodynamic simulation of surface-water flow and transport to Florida Bay through the Southern Inland and Coastal Systems (SICS): U.S. Geological Survey Water-Resources Investigations Report 03-4287, 56 p.

U.S. Department of Interior, 2004, Science Plan in Support of Ecosystem Restoration, Preservation, and Protection in South Florida: Accessed September 2004 at http://sofia.usgs.gov/publications/reports/doi-scienceplan/DOI-SCIENCE-PLAN-04.pdf.

Wolfert, M.A., Langevin, C.D., and Swain, E.D., 2004, Assigning boundary conditions to the Southern Inland and Coastal Systems (SICS) model using the results from the South Florida Water Management Model (SFWMM): U.S. Geological Survey Open-File Report 2004-1195, 30 p.

\section{For more information, contact:}

Christian Langevin, U.S. Geological Survey, Florida Integrated Science Center-Water and Restoration Studies, 9100 NW 36th Street, suite 107, Miami, FL 33178, Phone: 305-717-5817, Fax: 305-717-5801, Email: langevin@usgs.gov 